\title{
CU PRIVIRE LA GRANIȚA DE SUD-VEST A DACIEI ROMANE (II). Sectorul Porților de Fier
}

Doina Benea

About the south-western border of Roman Dacia (II). The Iron Gates sector

The Iron Gates region has a special situation on the Roman border. This is due to several causes, the main one being the difficulties of navigation in this sector in at least three areas: Cazanele Mari, Cazanele Mici and the Iron Gates itself (with statio Cataractarum). In the first two cases, the difficulty of navigation was so great due to the strong currents in the narrow area of the river within the mountains that imposed the supervision of the fluvial traffic. The small width of the Danube in this sector, of just a few hundred meters, might ease a barbarian or any other kind of attack on the settlements from the banks of the Danube.

There are two different opinions expressed in the literature: the first one states that the presence of the same auxiliary troupes on both sides of the Danube might argument this territory belonged to Upper Moesia ${ }^{1}$; the second opinion considers possible the military union of the two provinces in great military distress times ${ }^{2}$, such as the Marcomannic wars, when the unique command of the two Dacian provinces and the Upper Moesia was given to M. Claudius Fronto.

To this situation, mainly determined by natural causes, we must add the attacks of the free Dacians upon the Lower Danube provinces during the reign of Antoninus Pius, that occurred in a general context of attacks over to Roman Empire border (Germania, Africa, Parthian movements etc.), but most probably they were determined by certain movements of the barbarian European tribes that pressed upon the populations in the near vicinity of the Roman borders.

It is possible that after the attacks in 155-157 the middle earth wall that crossed the south-west region of Dacia was raised, becoming the provincial border in this sector ${ }^{3}$. These military events are, with good reason, considered a prelude of the Marcomannic wars.

The situation continued in the following decades. The troupes were maintained on both sides of the Danube even after these events, because the peace was heavily established, after almost two decades of wars with the Marcomanmians and other people, and in the III $^{\text {rd }}$ century this was seen as the only possibility to control the entire area.

Cuvinte cheie: Dacia, Moesia Superior, armată romană, frontieră, castre.

Key words: Dacia, Moesia Superior, roman army, frontier, castra.

În precizarea graniței de sud dintre provinciile Dacia şi Moesia Superior, respectiv pe linia fluviului Dunărea, situația apare clară la prima vedere, prin faptul că, în mod logic, malul de nord al fluviului ar reprezenta limita provinciei Dacia în acest sector, aşa cum cel de sud este dependent de Moesia Superior.

Şi totuşi, prezența în diferite momente din timpul secolelor II-III p.Chr. a unor detaşamente din legiunile IIII Flavia şi VII Claudia în mai multe centre fortificate de pe malul

\footnotetext{
${ }^{1}$ The first one who advanced this idea was Radnoti 1975, 203-214; the idea was reprised by many others, see the entire bibliography of the issue at Gudea 2001.

${ }^{2}$ Benea 1987, 67-70.

${ }^{3}$ Benea 2007a, in print.
} 
de nord al fluviului (ca, de pildă, Pojejena, Gornea, Drobeta), alături de anumite trupe auxiliare (precum cohors I Cretum, cohors V Gallorum, Cohors III Campestris, cohors II Gallorum Macedonica etc.), care apar documentate la scurte intervale de timp, când în provincia Dacia, când în provincia sud-dunăreană Moesia Superior, face greu de înțeles care era traseul graniței dintre cele două provincii.

Explicarea acestei situaţii a fost diferit percepută de lumea ştiinţifică. În literatura de specialitate s-au conturat două opinii diametral opuse: prima conform căreia prezenţa aceloraşi trupe auxiliare pe ambele maluri ale Dunării ar argumenta apartenența acestui teritoriu la provincia Moesia Superior ${ }^{4}$ şi o a doua părere, care consideră posibilă unificarea din punct de vedere militar a celor două provincii - Dacia şi Moesia Superior - doar în momente de mare criză militară $\breve{5}^{5}$, cum a fost de pildă, în timpul războaielor marcomanice, sub o comandă unică, cea din timpul lui M. Claudius Fronto (168-170).

Evoluția discuțiilor în literatura de specialitate a tins spre a suș̦ine că, totuşi, în timpul existenței provinciei Dacia, malul de nord al fluviului cu castrele şi aşezările sale şi chiar întreg teritoriul Banatului ar fi depins de Moesia Superior ${ }^{6}$. Întreaga argumentaţie se bazează pe prezența în diplomele militare din cele două provincii la câteva decenii distanță a unor trupe auxiliare care au fost transferate când pe un mal, când pe altul, în diferite momente ale secolului II. Explicațiile oferite până acum au avut la bază mențiunile din diplomele respective apărute în ambele provincii sau prezența unor inscripții şi ştampile descoperite în fortificațiile de pe ambele maluri ale Dunării la anumite intervale de timp.

Este deja prea bine cunoscut faptul că în timpul evenimentelor militare declanşate de cucerirea Daciei de către romani un număr mare de trupe auxiliare din provincia Moesia Superior (existente anterior sau aduse în mod special pentru aceste evenimente) au participat la războaie şi apoi au fost amplasate la nord de Dunăre, în noua provincie Dacia ${ }^{7}$.

În primele diplome militare ale provinciei Dacia din anii 109 şi 110 apar amintite mai multe trupe auxiliare care proveneau din Moesia Superior ${ }^{8}$. După cucerirea Daciei, un număr important de trupe auxiliare au fost retrase din Pannonia Inferior, Moesia Superior, Moesia Inferior şi au format armata provinciei nord-dunărene. În cazul unor evenimente militare în provinciile vecine, încă din timpul domniei lui Traian se constată implicarea trupelor auxiliare din Dacia. De pildă, în evenimente militare din Pannonia Inferior din anul 108, ceea ce evidențiază începutul creării unor zone de activitate militară comună între provinciile limitrofe ${ }^{9}$.

În fortificațiile dispuse în regiunea Porților de Fier, pe malul de sud al Dunării, nu avem indicii clare asupra prezenței unor garnizoane romane începând cu epoca lui Hadrian. În noul context istoric, întrucât ambele maluri ale fluviului se aflau sub control roman, nu se impunea o prezență activă militară, poate doar pentru supravegherea navigației, având în vedere caracterul internațional al traficului pe Dunăre, unde corăbii romane, dar şi barbare civile circulau în mod curent. $\mathrm{Cu}$ alte cuvinte, Dunărea oferea posibilitatea ca în afară de corăbiile romane, să fi existat, cum este firesc, şi ambarcațiuni sau bărci monoxile barbare, care participau la traficul fluvial în scop comercial sau, de ce nu, de jaf. La aceasta, se adaugă dificultățile de navigație specifice din zona Porților de Fier.

\footnotetext{
${ }^{4}$ Primul care a avansat această idée a fost Radnoti 1975, 203-214, ea a fost reluată de mulți alții, vezi întreaga bibliografie a problemei la Gudea 2001.

${ }^{5}$ Benea 1987, 67-70.

${ }^{6}$ Gudea 2001, cu toată bibliografia până la aceea dată.

${ }^{7}$ Vezi CIL XVI 46 (anul 100); AE 1912, 218 (anul 103).

${ }^{8}$ IDRE II 302 (pentru anul 109); IDR I 2, 3 (pentru anul 110).

${ }^{9}$ Vezi diploma de la Tököd (CIL XVI 164), din anul 110.
} 
Care era statutul acestui trafic, cum era el reglementat juridic este greu de reconstituit. $\mathrm{Nu}$ deținem în acest moment prea multe date. Faptul că ulterior, după doar câteva decenii, împăratul Marcus Aurelius le va interzice iazigilor să mai dețină corăbii proprii, ca să nu se apropie de insulele de pe Dunăre în scop de jaf, este un indiciu evident al existenței unui astfel de trafic "internațional" ${ }^{10}$. Interdicția impusă de Marcus Aurelius a fost ulterior ridicată de către împăratul Commodus.

Se putea crede că în această situație un control al anumitor puncte din acest sector lung care începe undeva în preajma castrului de la Pojejena şi ajunge până la Drobeta ar fi fost de ajuns.

Regiunea Cazanelor, prin defileul său muntos, a constituit o zonă care i-a obligat pe romani să ia măsuri de securitate, foarte probabil imediat după anul 118, prin instalarea de detaşamente militare de o parte şi de alta a Dunării. În provincia Moesia Superior, alături de cele două legiuni, VII Claudia Pia Fidelis şi IIII Flavia Felix (retrasă în anul 114 din provincia Dacia) $^{11}$, se mai afla doar cohors V Hispanorum la Cuppae (Golubac) ${ }^{12}$.

Pe baza descoperirilor arheologice, P. Petrović a propus o analiză asupra posibilelor sedii ale unor unități ale flotei de pe teritoriul Moesiei Superior, în sectorul Dunării cuprins între localitățile Singidunum - Ratiaria ${ }^{13}$, identificând urmele unor amplasamente portuare militare în punctele Porečka Reka, Brza Palanka, Hajdučka Vodenica şi Kusjlak (Fig. 2).

Instalații portuare au fost investigate arheologic pe malul românesc al Dunării la Drobeta, Ostrovul Mare şi poate Gârla Mare ${ }^{14}$, confirmând existența unor amenajări portuare militare. Nu avem nici un indiciu arheologic pentru o astfel de construcție la Dierna, unde ea nu putea lipsi. Ele demonstrează existența unor amenajări speciale militare ale flotei pentru supravegherea navigației pe Dunăre.

Cât de de mult erau aceste porturi militare apărate de către unităţi militare este greu de precizat în acest moment. Cert este faptul că timp de câteva decenii în acest sector fluvial nu sunt semnalate evenimente militare deosebite şi nici anumite mişcări de trupe sau transferuri de alte unități militare.

În lipsa auxiliilor corespunzătoare în Moesia Superiorau fost instituite, probabil, mici unităţi din legiunile VII Claudia şi IIII Flavia. Până în aceste moment deținem puţine informații epigrafice referitoare traficului fluvial de pe Dunăre, în zona Cazanelor.

O inscripție funerară descoperită la Naissus menționează un soldat: L. Cassius Candidus miles leg(ionis) VII Cl(audiae) disce(n)s epibeta(!)(sn) vi[x(it)] an (nis) XXI, m(ensibus)...d(iebus) IIII $m$ [il(itavit)] ann(nis) ${ }^{15}$. Gradul de discens epibeta face parte din corpul de principales al marinei romane. Acest grad apare documentat atât pe Rin, dar şi pe Dunăre ${ }^{16}$. Inscripția oferă singura informație referitoare la prezența unor soldați de infanterie marină din cadrul legiunii VII Claudia. Misiunea lor era probabil aceea de a efectua serviciul în patrulare pe Dunăre ${ }^{17}$. Nu avem indicii clare arheologice privind evoluția cronologică a castrelor aflate pe malul de sud al Dunării. De regulă, după anul 106, când s-a format provincia Dacia, ele au fost abandonate. Cercetările arheologice de salvare din aceste castre determinate de construirea Hidrocentralei de la Porțile de Fier au identificat o fază de refacere în timpul lui Septimius Severus, ceea ce ar însemna cca. 100 de ani fără nici un fel de reparații construtive la aceste fortificații ${ }^{18}$. Implicit,

\footnotetext{
${ }^{10}$ SHA, Vita M. Aurelii, 24.

${ }^{11}$ Benea 1983, 52-56.

${ }^{12}$ CIL III 8262, 14575, vezi şi Benea 1987, 58.

${ }^{13}$ Petrović 1989-1990, 207-216.

${ }_{15}^{14}$ Stângă 1998, passim.

${ }^{15}$ IMS IV 31.

${ }^{16}$ Starr 1961, 192.

${ }^{17}$ Benea 1987, 58.

${ }^{18}$ Vezi întreaga discuție la Gudea 2001, 29-41.
} 
ar însemna că ele nu au fost utilizate. Din această cauză, nici pentru o evoluție cronologică a trupelor auxiliare în provincie nu apare destul de clar poziţia lor, în contextul stratigrafic.

S-ar părea că până la apariția unor mențiuni privind trupe auxiliare retrase din Dacia, nu avem documentată decât prezența unor vexilații din legiunile Moesiei Superior, VII Claudia şi IIII Flavia, care deveniseră fie eşaloane pentru marile campanii din Orient, fie dimpotrivă au suplinit lipsa altor legiuni din provinciile limitrofe (vezi în timpul lui Marcus Aurelius prezența legiunii IIII Flavia la Aquincum) ${ }^{19}$. Aşa s-ar explica situația constatată în zona Porților de Fier în secolul II p.Chr. În mai multe castre aflate pe malul de sud al fluviului au apărut ştampile (mai ales) ale legiunii VII Claudia, dar şi ale legiunii IIII Flavia. Lipsa pe anumite tegule ştampilate a epitetelor de pia fidelis (pentru legiunea a VII Claudia) şi felix (pentru legiunea IIII Flavia) sunt indicii ale datării lor după domnia lui Hadrian când aceste două epitete nu mai sunt în uzanță $\breve{a}^{20}$. Trebuie să recunoaştem că astfel de ştampile în lipsa unei tipologii riguroase se pot data până spre finele secolului III p.Chr. Ele sunt documentate la Cuppae (Golubac) ${ }^{21}$, Novae (Čezava) $)^{22}$, Boljetin-Gradac ${ }^{23}$, Taliata (Donji Milanovac) ${ }^{24}$, Transdierna (Tekija) ${ }^{25}$, Statio Cataractarum $^{26}$, Karataş $^{27},(\text { Kladovo })^{28}$, Pontes (Kostol) ${ }^{29}$, Bononia (Vidin) ${ }^{30}$. Pe malul de nord al Dunării ştampile ale legiunilor din Moesia Superior apar la Banatska Palanka ${ }^{31}$, Pojejena ${ }^{32}$, Moldova Veche ${ }^{33}$, Gornea ${ }^{34}$, Dierna $^{35}$, Drobeta $^{36}$.

Uneori, ştampilele tegulare sunt asociate cu ştampile de trupe auxiliare fără a se putea dovedi de când datează acestea. Se conturează, deci, o primă situație şi anume imediat în epoca lui Hadrian prezența detaşamentelor din legiunile provinciei în spațiul Regiunii Porţilor de Fier, în castrele de pe malul Moesiei Superior.

În timpul lui Antoninus Pius, judecând după mai multe diplome militare emise pentru Moesia Superior recent descoperite, în componența armatei acesteia apar menționate trupe

\footnotetext{
${ }^{19}$ Benea 1983, 55-60.

${ }^{20}$ Benea 1983, passim.

${ }^{21}$ Gudea 2001, 61, nr. 11, ştampile ale legiunii a VII Cl(audia) şi ale cohors I Fl(avia) Hisp(anorum) (milliaria).

${ }^{22}$ Gudea 2001, 63-65, ştampile în cartuş ale legiunii a VII Cl(audia).

${ }^{23}$ Gudea 2001, 67-68, inscripție incizată cu numele legiunii a IIII Flavia şi ştampile ale legiunii a VII Claudia.

${ }^{24}$ Gudea 2001, 70-72, ştampile tegulare legiunea VII Claudia şi cohors I Lusitanorum (secolul I).

25 Gudea 2001, 73-74. Într-o monografie publicată recent (în anul 2004) de Al. Čermanović-Kuzmanović asupra cercetărilor arheologice efectuate la Tekija se prezintă principalele rezultate. Cercetările au fost extreme de dificile datorită suprapunerii aşezării moderne asupra sitului antic. $\mathrm{Nu}$ avem indicii concludente asupra structurii interne a castrului. Ştampilele tegulare descoperite aparțin unor trupe auxiliare V Gallo(rum) şi VIIII Gemina Vol(untariorum), alături de vasul de capacitate din bronz cu inscripția: COH.V. GALL./EXACTA/AT.LEG VII C. RE. sunt singurele indicii databile în secolele I-IV p.Chr. Surprinzător, în cadrul descoperirilor monetare după epoca lui Traian şi până în timpul lui Gordianus III (238-244) prezența monedelor romane în secolul II este de mică (doar două monede de la Marcus Aurelius). Acest hiatus explică ceva şi anume slaba prezență militară în acest areal, fără a putea nega eventuala staționare a unui detaşament din cohors V Gallorum pentru un scurt timp. Nu avem posibilitatea de a face o tipologie a ştampilelor trupei, întrucât, din păcate, descoperirile din Dacia de la Pojejena sunt fragmentare. Ca atare, nu considerăm îndeajuns de concludentă părerea exprimată de mai mulți cercetători, potrivit căreia putem vorbi de o staționare îndelungată a trupei de la Pojejena la Tekija.

${ }^{26}$ Rankov 1987, 16-36; Kondić 1987, 39-41 menționează inscripții votive şi onorifice ale unor militari din legiunile provinciei.

${ }^{27}$ Gudea 2001, 75-78 (inscripție a unui centurion din cohors V Gallorum Antoniniana, şi o inscripție incizată cu cohors VI Thracum.

${ }^{28}$ Gudea 2001, 78-79, ştampile tegulare ale legiunii a VII Claudia, cohors I Cretum şi cohors III Brittonum.

${ }^{29}$ Gudea 2001, 79-80, ştampile tegulare ale lui cohors I Cretum, cohors II Hispanorum şi cohors III Brittonum.

${ }^{30}$ Gudea 2001, 92-93.

${ }^{31}$ Gudea 2001, 57, nr. 8, cu bibliografia până la aceea dată.

${ }^{32}$ Gudea 2001, 59, stampile ale ambele legiuni: VII Cl(audia) şi a IIII FL(avia) alături de Coh. V Gal(lorum).

${ }^{33}$ Benea 2008, 24-26.

${ }^{34}$ Gudea $1977,12-14$

${ }^{35}$ Gudea 2001, 74, nr. 15.

36 Gudea 2001, 81-85, ştampile tegulare ale legiunii a VII Claudia, dar şi ale unor cohortes: I Cretum, I Sagittariorum, III Brittonum, VII Breucorum Antoniniana; C(lassis) F(lavia) M(oesica) etc. Sunt menționate doar cele databile până la abandonarea Daciei.
} 
auxiliare noi, care au fost retrase din provincia Dacia şi transferate în provincia sud-dunăreană începând cu anii 155/157 (judecând după cele mai recente descoperiri) ${ }^{37}$.

Prezența în Moesia Superior a unor trupe auxiliare romane retrase din Dacia a fost interpretată, ca o urmare a extinderii juridice a graniței şi pe malul de nord al Dunării ${ }^{38}$. Noi credem că explicațiile date până acum pentru o astfel de situație nu au fost îndeajuns de coerente şi logice şi, mai ales, nu au ținut cont de contextul politico-militar de la Dunărea de Jos din anumite perioade ale secolului II. Trupele auxiliare erau prin excelență trupe de infanterie, lucru firesc având în vedere zona de activitate şi mai ales activitatea militară pe care trebuiau să o desfăşoare.

În tabelul sinoptic de mai jos, apar amintite mai multe unități militare menționate în diplomele din anii 156/157 $7^{39}, 155 / 159,158 / 159,159 / 160,161^{40}$, care aparțin provinciei Moesia Superior. Ulterior, în diploma din anul 179 o parte din acestea revin în provincia Dacia.

\begin{tabular}{|c|c|c|c|c|c|c|c|c|c|c|}
\hline $\begin{array}{c}\text { Denumirea } \\
\text { trupei }\end{array}$ & $\begin{array}{c}\text { Sediu în } \\
\text { Dacia }\end{array}$ & $\begin{array}{c}\text { Anul } \\
109 \\
\text { (IDRE } \\
\text { II 302) }\end{array}$ & $\begin{array}{c}\text { Anul } \\
110 \\
(I D R \\
\text { I2,3) }\end{array}$ & $\begin{array}{c}\text { Transfer } \\
\text { în Moesia } \\
\text { Superior }\end{array}$ & $\begin{array}{l}\text { Anii } \\
156 / \\
157\end{array}$ & $\begin{array}{c}\text { Anii } \\
155 / \\
159 \\
\text { (AE } \\
1998, \\
1617 \text { ) }\end{array}$ & $\begin{array}{c}\text { Anii } \\
158 / \\
159 \\
\text { AE } \\
1999, \\
1315\end{array}$ & $\begin{array}{c}\text { Anii } \\
159 / \\
160 \\
\text { CIL } \\
\text { XVI } \\
111\end{array}$ & $\begin{array}{c}\text { Anul } \\
161 \\
\text { RMD } \\
55\end{array}$ & $\begin{array}{c}\text { Transfer } \\
\text { în Dacia } \\
\text { (ZPE 56, } \\
\text { 1984) } \\
\text { anul 179 }\end{array}$ \\
\hline $\begin{array}{l}\text { Ala Claudia } \\
\text { nova misce }\end{array}$ & - & - & - & - & - & - & - & - & $\mathrm{x}$ & \\
\hline $\begin{array}{l}\text { Ala Gallorum } \\
\text { Flaviana }\end{array}$ & - & - & - & - & - & - & - & $\mathrm{x}$ & $\mathrm{x}$ & \\
\hline Coh. I Ant. sag & Drobeta & - & - & Necunoscut & & $\mathrm{x}$ & $\mathrm{x}$ & $\mathrm{x}$ & $\mathrm{x}$ & \\
\hline $\begin{array}{l}\text { Coh. III. } \\
\text { Gallorum }\end{array}$ & $\begin{array}{l}\text { Ioneştii } \\
\text { Govorii } \\
\end{array}$ & $\mathrm{x}$ & $\mathrm{x}$ & $?$ & & & & & $\mathrm{x}$ & \\
\hline $\begin{array}{l}\text { Coh. V } \\
\text { Gallorum }\end{array}$ & Pojejena & $x$ & $\mathrm{x}$ & $\begin{array}{c}\text { Transdierna } \\
\text { (Tekija) }\end{array}$ & $x$ & $\mathrm{x}$ & $\mathrm{x}$ & $\mathrm{x}$ & $\mathrm{x}$ & $\mathrm{x}$ \\
\hline $\begin{array}{l}\text { Coh. II } \\
\text { Gallorum } \\
\text { Macedonica }\end{array}$ & Necunoscut & $\mathrm{x}$ & $\mathrm{x}$ & ? & $\mathrm{x}$ & - & - & - & $\mathrm{x}$ & $\mathrm{x}$ \\
\hline $\begin{array}{l}\text { Coh. I } \\
\text { Pannoniorum }\end{array}$ & Necunoscut & $\mathrm{x}$ & $\mathrm{x}$ & Ritopek & & $\mathrm{x}$ & & $\mathrm{x}$ & $\mathrm{x}$ & \\
\hline $\begin{array}{l}\text { Coh. III } \\
\text { Campestris }\end{array}$ & $\begin{array}{c}\text { Drobeta, } \\
\text { Trans- } \\
\text { drobeta }\end{array}$ & & $\mathrm{x}$ & $\begin{array}{c}\text { Aquae, } \\
\text { Dorticum, } \\
\text { Viminacium }\end{array}$ & $\mathrm{x}$ & $\mathrm{x}$ & $\mathrm{x}$ & $\mathrm{x}$ & $\mathrm{x}$ & $\mathrm{x}$ \\
\hline
\end{tabular}

\footnotetext{
${ }^{37}$ Vezi Benea 2009.

${ }^{38}$ Gudea 2001, 29-34.

${ }^{39}$ Petolescu 2002, 92, nota 10.

${ }^{40}$ AÉ 1998, 1617; Petolescu 2002, 92, nota 10; AÉ 1999, 1315; CIL XVI 111; RMD 55.
} 


\begin{tabular}{|c|c|c|c|c|c|c|c|c|}
\hline Coh.I Cretum & $\begin{array}{c}\text { Drobeta, } \\
\text { Banatska } \\
\text { Palanka }\end{array}$ & & $\mathrm{x}$ & $\begin{array}{c}\text { Ratiaria } \\
\text { (Arčar), } \\
\text { Vidin, Aquae } \\
\text { (Prahovo) }\end{array}$ \\
$\begin{array}{c}\text { Coh. I } \\
\text { Montanorum }\end{array}$ & Necunoscut & & $\mathrm{x}$ & $\begin{array}{c}\text { Novae } \\
\text { (̌ezava) din } \\
\text { anul 110 în } \\
\text { Pannonia } \\
\text { Inferior }\end{array}$ & $\mathrm{x}$ & - & - & \\
\hline
\end{tabular}

Alături de aceste unităţi militare, au mai fost retrase din Dacia în Moesia Inferior alte două trupe şi anume I Thacum Syriaca şi I Bracaraugustanorum, prezente într-o diplomă din anii 145/146 ${ }^{41}$. O a treia unitate retrasă din Dacia a fost cohors IV Cypria de la Bumbeşti, trimisă la Olbia în războiul cu taurosciții ${ }^{42}$.

Aceste mişcări de trupe în provinciile de la Dunărea de Jos evidențiază un aspect atins tangențial doar de unii cercetători ${ }^{43}$ : ele au fost urmarea unor evenimente militare externe. În acest caz, trebuie să fie vorba, probabil, de atacurile dacilor liberi asupra Imperiului Roman.

Evenimentele propriu-zise nu sunt cunoscute în detaliu, dar mențiunea expresă din anul 144 a lui Aelius Aristides ${ }^{44}$ privind războiul pricinuit de nebunia geților arată clar depăşirea conflictului militar anterior (anul 143).

Pe teritoriul Daciei Superior este cunoscut un singur depozit monetar la Dâmbau (jud. Mureş), ceea ce poate indica direcția atacului asupra provinciei, venit dinspre Moldova. Provincia avea atunci în dispozitiv doar legiunea a XIII Gemina şi mai multe trupe auxiliare, care au putut participa la evenimente ${ }^{45}$. Dar, se pare că aceste atacuri ale dacilor liberi şi ale aliaţilor lor nu au afectat în mod special provincia Dacia. Situaţia militară a Daciei a permis luarea deciziei de transferare a unor unități la sud de Dunăre.

Un indiciu al încheierii conflictului militar şi implicit de pacificare a provinciei este demonstrat de emiterea diplomei din 23 februarie 144, prin care s-au făcut masive lăsări la vatră din trupele din Dacia Superior, în timpul legatului Q. Mustius Priscus ${ }^{46}$. Profesorul M. Macrea, necunoscând la data respectivă diploma de la Micia din anul 137 a Daciei Superior, descoperită relativ recent ${ }^{47}$, presupunea prezența mai multor trupe auxiliare noi aduse pe teritoriul provinciei. Desigur, o lăsare masivă la vatră în anul 144 presupunea deja existența unei perioade de linişte după evenimente militare amintite.

O situație de nesiguranță apare în timpul lui Antoninus Pius în provincia Moesia Inferior, unde mai multe depozite monetare de denari se concentrează la sud de Dunăre pe lângă

\footnotetext{
${ }^{41}$ Weiss 1999, 279-286.

${ }^{42}$ Petolescu 2002, 85

${ }^{43}$ Chițescu 1971, 401-410; Gudea 2001, 42-44, cu bibliografia; Benea 2009.

${ }^{44}$ Aelius Aristides, XXVI, 70: "...Războaiele.... pricinuite de nebunia geților, de soarta nefericită a libienilor sau de sminteala celor din jurul mării Roşii care nu ştiu să se bucure de bunurile ce le stau la îndemână, aceste războaie trec cu totul neluate în seamă, repede... şi la fel şi cele spuse despre ele ”; Historia Augusta, Vita Pii, 5,4, relatează: " ... cele mai multe războaie le-a dus prin generalii săi. Pe britani i-a învins prin generalul Lollius Urbicus ridicând, după ce a respins pe barbari, un alt zid de pământ de-a lungul graniței. Pe mauri $i-a$ silit să ceară pace. Pe germani, pe daci (sn) şi pe multe alte neamuri, ca şi pe iudeii răsculați, $i-$ a respins prin guvernatori şi generali...".

${ }^{45}$ Benea 2009.

${ }^{46}$ IDR I 14, vezi şi comentariul la Macrea 1969, 55

${ }^{47}$ Petolescu 2003-2005, 85-86.
} 
oraşele Abrittus (1), Marcianopolis (1), Oescus (1), Gaitanci (1), Lucovica (1) şi Bononia (Vidin) (3), centre în care, cu excepția coloniei Oescus, nu se aflau trupe romane ${ }^{48}$.

Judecând după locul de descoperire al unor tezaure monetare dispuse în Moesia Inferior, de-a lungul Dunării şi pe căi de acces spre interiorul provinciei, trebuie să presupunem că principalul atac al dacilor liberi şi al aliaţilor lor a continuat pe Dunăre cu corăbiile, apropiindu-se de malul sudic al fluviului, acolo unde existau zone nepăzite care le-au oferit posibilitatea de a pătrunde de-a lungul unor cursuri de apă, în interiorul provinciei ${ }^{49}$. Ele marchează căi de acces spre trecătorile Munților Balcani şi înspre provincia Thracia.

Dispersia locului de descoperire al acestor tezaure dovedeşte existența unui atac barbar care se desfăşoară de-a lungul Dunării, cu ajutorul corăbiilor şi care a încercat să pătrundă în provincie, surprinzând nepregătită apărarea Moesiei Inferior şi Thraciei ${ }^{50}$. Datarea acestor evenimente ar fi avut loc, în opinia lui B. Gerov, în anii 139 şi $143-144^{51}$.

Dovada că atacul dacilor liberi a fost concomitent sau la scurt timp după cel din Dacia rezultă şi din diploma acordată pentru Moesia Inferior în anii 145/146, unde apar menţionate şi cele două unităţi retrase din Dacia - cohors I Thracum Syriaca şi cohors I Bracaraugustanorum $^{52}$. Nu avem indicii ferme asupra situaţiei din Moesia Superior şi dacă aceste atacuri au afectat provincia, dar este semnificativ faptul că malul de nord al Dunării, între vărsarea Oltului în Dunăre şi Drobeta, nu dispunea de nici o unitate militară, ceea ce poate fi considerată o carență gravă de apărare, cu atât mai mult cu cât şi pe malul de sud al Dunării ele erau prezente poate doar la Oescus, Novae ${ }^{53}$.

Consecința imediată a acestor dificultăți militare în spațiul sud-dunărean, a fost luarea unor măsuri de reorganizare militară a provinciilor Moesia Superior şi Moesia Inferior, prin aducerea unor noi corpuri de trupă auxiliare şi implicit reactivarea unor fortificații de pe linia Dunării abandonate după cucerirea Daciei (ne referim la Moesia Superior) ${ }^{54}$. Pe de altă parte, ele veneau să suplinească lipsa efectivelor trimise în războiul contra maurilor din anii 144-149, în principal a legiunii IIII Flavia sau doar a unui corp expediționar din aceasta ${ }^{55}$.

Datarea diplomelor militare ale Moesiei Superior în anii ce urmează după 155 argumentează în chip evident momente legate aceleaşi evenimente. Retragerea acestor trupe auxiliare din Dacia la sudul Dunării venea după prima invazia barbară din anii 143-144, care a afectat în principal cele două provincii Moesia ${ }^{56}$.

În sfârşit, o diplomă militară a Moesiei Superior din timpul lui Antoninus Pius menționează şi aducerea unei unității neregulate de Mauri equites et pedites ${ }^{57}$. O unitate similară însoțită de Vexillari Africae et Mauretaniae Caesariensis ajunge şi în Dacia Superior ${ }^{58}$. Toate evidenţiază momente dificile din punct de vedere militar pentru ambele provincii ${ }^{59}$.

\footnotetext{
${ }^{48}$ Gerov 1977, 117-118.

${ }^{49}$ Benea 2009.

${ }^{50}$ Gerov 1977, 117-118.

${ }^{51}$ Gerov 1977, 117-118.

${ }^{52}$ Weiss 1999, 279-286.

${ }^{53}$ Benea 2009.

${ }^{54}$ Benea 2009.

${ }^{55}$ Benea 1983, 166-167.

${ }^{56}$ Benea 2009, prezența unităților din Dacia în Moesia Superior menționate în anii 155/157 poate să fi premers al doilea eveniment major al atacurilor dacice, petrecut chiar în aceea perioadă (dacă nu cumva aici nu dispunem încă de nici informație epigrafică concludentă, asemeni diplomei din anii 145/146 din Moesia Inferior).

${ }^{57}$ CIL XVI 114.

${ }^{58}$ Diploma de la Cristeşti, din 8 iulie 158 (IDR I 16).

${ }^{59}$ Într-o lucrare recentă, C. Onofrei $(2007,271)$ avansează mai multe ipoteze privind existenţa trupelor de mauri în Dacia, între care şi aceea potrivit căreia lectura diplomei descoperită la Răcari în care sunt pomeniţi Mauris eq/uitibus/ et pedi(tibus)/ qui sunt in /Moe/sia Sup(eriore) ar trebui citit /Dac/ia Sup(eriore). Mențiunea unei cohors Maurorum într-o diplomă descoperită la Kostolac, care menționează un personaj originar din Bassiana cu numele de
} 
Între anii 155-157/158, spre sfârşitul domniei lui Antoninus Pius, se pare că izbucnesc noi incidente cu dacii liberi. La început, atacul dacilor liberi asupra provinciei Dacia a avut loc tot dinspre Moldova, judecând după anumite depozite monetare descoperite în partea de est a provinciei $^{60}$, la Bereni ( un depozit monetar din 57 monede de bronz alături de un fragment de

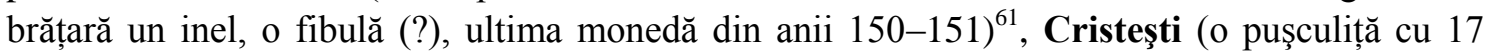
monede, ultima din anul 152) ${ }^{62}$, Sălaşuri (tezaur format din 3200 de monede, ultima din anul 158) ${ }^{63}$, Sighişoara (jud. Mureş) (tezaur format din 48 de monede ultima de la Aurelius Caesar) ${ }^{64}$, Vişea (jud. Cluj) (tezaur din 86 denari, ultima monedă 156), sugerând un pericol venit din zona Moldovei de nord şi centrale ${ }^{65}$. Un alt argument pentru acest eveniment militar îl constituie depozitul de vase din bronz şi unelte din fier (agricole) asociate cu o monedă de la Antoninus Pius ,descoperit în castrul de la Orheiul Bistriței (jud. Bistrița) ${ }^{66}$.

În afara provinciei Dacia, pe teritoriul Moldovei sunt cunoscute alte depozite monetare care se încheie cu monede de la Antoninus Pius, fără a putea preciza cărui eveniment pot fi atribuite (între 143-155): Avra (jud. Vrancea) ${ }^{67}$ Benești (jud. Bacău) ${ }^{68}$, Bozieni (jud. Neamț $)^{69}$, alături de celelalte menționate mai sus de la Brăeşti şi Buciumi. Ele indică în bună măsură drumul urmat de atacatori spre Dunăre şi Moesia Inferior.

Indirect pentru aceasta pledează şi diploma militară din anul 158 de la Cristeşti, pe care apar numele a 7 unităţi auxiliare: 3 ale ala I Batavorum (Războieni), ala I Hispanorum Campagonum (Micia), ala Gallorum et Bosporanorum (Cristeşti) ${ }^{70}$ şi trei cohorte: cohors I Ubiorum (Odorheiu Secuiesc, Ozd) ${ }^{71}$, I Thracum Sagittariorum (sediu neprecizat) ${ }^{72}$, IIII Hispanorum (Inlăceni) ${ }^{73}$ şi o unitate neregulată (vexillarii Africae et Mauretaniae Caesariensis et .......Mauri Gentilibus ${ }^{74}$. Diploma menționează trupe auxiliare aflate în majoritatea cazurilor în partea de est a provinciei, chiar în colţul ei de sud-est, ceea ce ar evidenția chiar meritele acestor trupe. Din toate unităţile menţionate doar două staţionau în partea de vest şi centrală a Daciei, respectiv cele două trupe de cavalerie: ala I Batavorum (Războieni), ala I Hispanorum Campagonum (Micia). Într-un fel, chiar depozitele monetare databile în anii 155/157 sunt aproape de amplasamentul trupelor auxiliare în discuție $^{75}$.

Trei diplome militare datând din anii 157-159, respectiv cea din 13 decembrie 157 Tibiscum, 8 iulie 158 - Cristeşti şi cea de la Domaşnea, din 27 septembrie $159\left(\right.$ (?) ${ }^{76}$, ar putea fi

\footnotetext{
T. Flavius T. f. Titianus, nu exclude posibilitatea ca unitatea respectivă să fi staționat în Moesia Superior şi nu Pannonia, cum presupune dl. Onofrei. Acest detaşament de mauri putea fi adus odată cu întoarcerea corpului expediționar al legiunii IIII Flavia din Mauretania (vezi mai sus nota 52).

${ }^{60}$ Chițescu 1971, 403.

${ }^{61}$ Suciu 2000, 26.

${ }_{62}^{62}$ Chițescu, 1971, 403; Suciu 2000, 34.

${ }^{63}$ Chițescu, 1971, 403; Suciu 2000, 52.

${ }^{64}$ Chițescu, 1971, 403.

${ }^{65}$ Chițescu, 1971, 403.

${ }^{66}$ Gaiu 2005, 215-225, depozitul a fost descoperit în anul 1904, s-a fragmentat. El a fost reconstituit de către C. Gaiu. Relaţia cu evenimentele în discuție este însă relativă şi o apreciez ca nesigură.

${ }^{67}$ Mihăilescu-Bîrliba 1980, 254.

${ }^{68}$ Mihăilescu-Bîrliba 1980, 254.

${ }^{69}$ Mihăilescu-Bîrliba 1980, 257.

${ }^{70}$ IDR I 16 cu comentariul prof. I.I. Russu.

${ }^{71}$ Petolescu 2002, 125.

${ }^{72}$ Petolescu 2002, 114-115.

${ }^{73}$ Petolescu 2002, 114-115.

${ }^{74}$ Petolescu 2002, 132.

${ }^{75}$ Benea 2009.

${ }^{76}$ IDR I 15, 16, 17.
} 
urmarea încheierii unor evenimente militare, când se impuneau masive lăsări la vatră. Acest lucru a fost susținut cu destul de mult timp în urmă de către M. Macrea ${ }^{77}$.

Inscripția binecunoscută dedicată Victoriei Augusta în locul numit Sub Cununi din Munții Orăştiei ar putea reprezenta momentul final al războaielor. Dar, tot aşa de bine putea servi pentru aniversarea celor 50 de ani de la cucerirea Daciei, cum s-a susținut de curând de către M. Bărbulescu ${ }^{78}$.

Pe de altă parte, având în vedere lăsările la vatră constatate după anul 155, s-ar părea că provincia Moesia Superior a fost şi ea afectată. În acest context, o serie de trupe au fost retrase din Dacia şi au apărut menționate la sud de Dunăre. În atare situație, nu trebuie exclusă posibilitatea unei pătrunderi barbare pe linia Tisei până la Dunăre.

$\mathrm{Nu}$ deținem informații despre un atac similar înspre provincia Moesia Inferior în acest timp. Astfel, s-ar contura în a doua parte a evenimentelor militare un atac generalizat asupra Daciei, marcat de o eventuală pătrundere în provincie, atât dinspre est, cât şi dinspre nord şi vest, unde însă nu se constată pătrunderea în provincie, situaţie pentru care şi alte diplome militare ale Daciei Porolissensis ${ }^{79}$, alături de cele ale Daciei Superior argumentează această supoziţie.

Din aceste 11 trupe auxiliare retrase din provincia Dacia în Moesia Superior, după două aproape decenii, doar cinci unități şi anume III Campestris şi V Gallorum, cohors II Hispanorum vor reveni din nou în Dacia Superior, respectiv Porolissensis, şi sunt menţionate în diplom de la Drobeta din anul $179^{80}$, ceea ce înseamnă că au fost integrate armatei din provincie, poate în timpul războaielor marcomanice. În Dacia Inferior revin la Brețcu cohors I Bracaraugustanorum, iar la Acidava (Enoşeşti) cohors I Thracum Syriaca.

$\mathrm{Ca}$ urmare a atacurilor întreprinse de dacii liberi în timpul lui Antoninus Pius la Dunărea de Jos, în anumite castre de pe malul de sud al Dunării în provincia Moesia Superior au rămas unele detaşamente din legiunile provinciei şi unităţile auxiliare amintite anterior. Retragerea unor contingente importante din Moesia Inferior (legiunea V Macedonica) şi Pannonia Inferior (legiunea I Adiutrix) pentru campania lui Lucius Verus în anul 161, a impus iarăşi anumite permutări şi dezechilibre în organizarea militară a Moesiei Superior şi anume legiunea IIII Flavia, alături de cohors I Pannoniorum veterana, a fost transferată la Aquincum ${ }^{81}$.

Izbucnirea războaielor marcomanice, la scurt timp după încheierea evenimentelor militare din Orient, în anul 167, a surprins parțial nepregătite provinciile dunărene, ale căror efective de abia se întorseseră. Literatura de specialitate tratează în chip diferit această problemă ${ }^{82}$. Dacia pare să fi fost implicată în aceste evenimente încă de la început, judecând după tăblițele cerate ascunse la Alburnus Maior ${ }^{83}$, apoi după tezaurele monetare descoperite la Apulum, Dumbrăvicioara, Barbura, Buciumi-Alba ${ }^{84}$ etc.

Atacurile barbare asupra provinciei nord-dunărene au avut loc pe mai multe direcții, dar una dintre aceastea a vizat şi o pătrundere de-a lungul Dunării cu corabiile, mai ales ale sarmaților iazigi, căci altfel nu poate fi convenabil explicată una din condițiile păcii încheiate mai târziu de Marcus Aurelius cu aceste triburi: interdicția de a avea corabii proprii şi de a se

\footnotetext{
${ }_{77}^{77}$ Macrea 1969, passim.

${ }^{78}$ Bărbulescu 2006, 125-136.

${ }^{79}$ IDR I 17.

${ }^{80}$ Piso, Benea 1984, 263-289.

${ }^{81}$ Benea 1983, 166-167; în urma acestei situații Moesia Superior va avea timp de câțiva ani, un legat de rang pretorian.

${ }^{82}$ Gudea 1994, 67-93, cu toată bibliografia referitoare la această problematică.

${ }^{83}$ Daicoviciu, Piso 1975, 162, susţin punctual că anul cel mai dificil pentru Dacia a fost anul 170 şi nu 167, idee preluată şi de Moga, Benea 1975, 133-136, însă având în vedere mai multe descoperiri epigrafice nici noi nu mai susținem această ipoteză (Doina Benea).

${ }^{84}$ Gudea 1994, 69.
} 
apropia de insulele de pe Istru ${ }^{85}$, ceea ce însemnă că în timpul evenimentelor militare s-au comis atacuri asupra satelor şi oraşelor aflate în preajma Dunării.

Informații asupra unor posibile atacuri pe linia Dunării nu apar prea clar evidențiate. La Singidunum într-o inscripție funerară este menționat numele Sereniei Quarta "ab hoste interfecta" ${ }^{\prime \prime 6}$, hostis având semnificația duşman din afara statului roman, iar termenul s-ar putea referi la aceste evenimente ${ }^{87}$.

Un alt monument descoperit la Golubac, menționează un ofițer activ, centurion din legiunea VII Claudia, cu numele de C. Valerius Macedonus, decedat în anul 168. Inscripția funerară poate fi pus în legătura cu anumite posibile evenimente din timpul războaielor marcomanice $^{88}$.

În această perioadă, detaşamente din legiunea VII Claudia au putut staționa la nord de Dunăre la Banatska Palanka ${ }^{89}$, Pojejena ${ }^{90}$, Moldova Nouă (paza minelor) ${ }^{91}$ Gornea $^{92}$, Drobeta ${ }^{93}$, întrucât în anul 168 legatul Moesiei Superior M. Claudius Fronto primise şi comanda Daciei Apulensis, având în subordinea sa trei legiuni. Unirea sub aspect militar demonstra faptul că cele două provincii erau lovite dinspre vest, din punga iazigă dintre Tisa şi Dunăre ${ }^{94}$.

În anii 169/170, M. Claudius Frono primeşte comanda celor trei Dacii şi din nou a Moesiei Superior, indiciu al unor dificultăți militare majore la granițele celor două provincii ${ }^{95}$. În Moesia Superior are loc o reorganizare a teritoriilor miniere şi se înființează 5 trupe auxiliare noi menite să asigure paza interiorului provinciei (cohortele I Aurelia Dardanorum, II Aurelia Dardanorum, II Aurelia eq. C.R., II Aurelia nova Pasinatum c.R., II Aurelia nova Sacorum) ${ }^{96}$.

După restabilirea situaţiei şi ridicarea la tron a lui Commodus nu apar informații epigrafice sau de altă natură asupra Regiunii Porților de Fier, însă devenise clar că era necesară paza ambelor maluri ale Dunării în acest sector, chiar în condiţii de pace. Aşa s-ar explica refacerea în epoca lui Septimius Severus (sau chiar mai înainte) a tuturor fortificațiilor mari de pe malul de sud al fluviului, refacere constatată arheologic ${ }^{97}$.

Odată cu epoca Severilor se conturează începutul unui nou sistem de organizare militară, care presupune deplasarea în mod curent a unor detaşamente din cele două legiuni ale Moesiei Superior în Dacia sud-carpatică.

Ele nu se întâlnesc numai în centrele militare dispuse de-a lungul malului de nord al Dunării, ci şi mult în interior, la Moldova Nouă, Bumbeşti, Aquae (Cioroiul Nou).

Staționarea lor nu cuprinde numai durata unei campanii, ci pare uneori întinsă pe parcursul mai multor ani, cum ar fi cazul la Bumbeşti - Vârtop, spre pildă.

Când începe acest lucru? Credem că undeva în timpul lui Maximinus Thrax Gordianus III, când aceste teritorii dacice sunt iarăşi afectate direct de atacurile daco-sarmatice, carpice etc. ${ }^{98}$ Dacia intracarpatică devine sarcina celor două legiuni, XIII Gemina şi V Macedonica, iar spațiul sud-carpatic primeşte în mod curent ajutorul Moesiei Superior.

\footnotetext{
${ }^{85}$ Cassius Dio LXX19, 2.

${ }^{86}$ IMS I 52; Benea 1983, 56.

${ }^{87}$ Vezi şi comentariul lui M. Mirković la IMS I 52.

${ }^{88}$ CIL III 6297.

${ }^{89}$ Gudea 2001, 57-58.

${ }^{90}$ Gudea 2001, 59-60.

${ }^{91}$ Benea 2008, passim.

92 Gudea 1974.

${ }^{93}$ Gudea 2001, 82-85.

${ }^{94}$ CIL III 13457 = IDR III/2 90; CIL VI 1377.

${ }^{95}$ Vezi nota 91.

${ }^{96}$ IMS I, p. 104-107, comentariul lui S. Dušanić.

${ }^{97}$ Gudea 2001, passim, cu toată bibliografia.

${ }^{98}$ Benea 2005, 171-185.
} 
Un alt exemplu revelator îl reprezintă prezența la Romula unei vexilații din legiunea VII Claudia pentru respingerea atacului din anul 245, din timpul lui Philippus Arabs ${ }^{99}$. Aducerea vexilației din Moesia Superior, la care se adaugă şi o alta, a legiunii XXII Primigenia, la nord de Dunare, cuprinde unități ce făcuseră parte din armata de campanie a lui Gordian al III-lea, mutate de către Philippus Arabs după încheierea evenimentelor cu parții.

Fără a se putea opera o datare precisă în afara cadrului larg al secolului al III-lea, sunt documentate cărămizi ştampilate ale legiunilor VII Claudia şi IIII Flavia în castrul de la Bumbeşti-Vârtop (atât în castru, cât şi în thermae) şi la Aquae (Cioroiul Nou) ${ }^{100}$. În primul caz, cele două castre de la Bumbeşti au apărat accesul direct spre defileul Jiului şi de aici spre Ulpia Traiana Sarmizegetusa; la Aquae, unde încă nu este prea bine precizată fortificația aflată în plină câmpie, aceasta apăra zona aflată dinspre Olt şi Dunăre ${ }^{101}$. Cel puțin în cazul descoperirilor de la Bumbeşti, mai bine precizate cronologic, staționarea pare să fie mai îndelungată, având în vedere participarea legiunilor moesice la refacerea termelor şi a castrului. Acest lucru putea să dateze dintr-o perioadă anterioară anului 245 , când avusese loc o invazie barbară în Dacia, poate tocmai legat de cea din anul $242^{102}$.

La aceasta se adaugă şi descoperirile din cele două fortificații de pe Dunăre, de la Drobeta şi Pojejena (poate şi Moldova Nouă). Se conturează astfel o concepție strategică romană de apărare a Daciei romane. Partea ei sudică, respectiv Oltenia, aflată în fața Moesiei Superior, a fost întărită cu detaşamente din cele două legiuni (VII Claudia şi IIII Flavia) pe când Dacia transilvană a intrat în atribuțiile celor două legiuni ale provinciei (XIII Gemina şi V Macedonica). Nici în acest caz nu credem că se poate vorbi de modificări juridice ale teritoriului celor două provincii romane. Prezența trupelor din provincia sud-dunăreană poate reprezenta urmarea unei măsuri directe luate de Gordian al III-lea în momentul plecării spre Orient pentru întărirea sistemului defensiv al Daciei în acest sector, după respingerea atacului barbar din anul 242.

O asemenea măsură putea fi impusă, poate, şi datorită includerii în armata de campanie a unui număr mare de auxilii din provincia nord-dunăreană. Deocamdată alte argumente în acest sens nu deținem, dar o astfel de decizie imperială venea şi ca urmare a implicării teritoriului nord-dunărean în timpul invaziei barbare. Nu cunoaştem condițiile de pace concrete după înfrângerea barbarilor, cu excepția uneia şi anume includerea lor cu efective militare în rândul aliaţilor, sub denumirea de germani şi goți, în armata de campanie împotriva parților ${ }^{103}$.

Concluzii. Situația constatată în Regiunea Porților de Fier, care reprezenta limita de sud a Daciei în acest sector, ar putea să apară acum în ochii cercetătorului modern drept anacronică. Ea este însă o situație specială apărută într-un sector al graniței romane. Acest lucru a avut la bază mai multe cauze, în primul rând dificultăţile de navigație în acest sector în cel puțin trei zone, Cazanele Mari şi Cazanele Mici şi Porțile de Fier propriu-zise (cu statio Cataractarum). În primele două cazuri, dificultatea navigației era atât de mare datorită curenților puternici în zona îngustă a fluviului între munți, încât în mod evident aici traficul fluvial trebuia supravegheat. Lățimea mică a Dunării în acest sector (de doar câteva sute de metri) putea facilita uşor un atac barbar sau de altă natură asupra aşezărilor aflate pe malurile Dunării. Canalul roman construit de Traian la Sip, lung de 3400 m, pe malul de sud al Dunării, permitea trecere printr-o zonă plină de stânci, cu mari vârtejuri de apă şi curenți, care au îngreunat navigația până în epoca modernă, când țările riverane au construit la sfârşitul secolului XIX un alt canal utilizat pentru traversarea Porților de Fier, până la construirea Hidrocentralei I.

\footnotetext{
${ }^{99}$ IDR II 324-428 şi doar o cărămidă ştampilată fragmentară (nr. 380).

${ }^{100}$ Marinoiu 2002, 83-88.

${ }^{101}$ Bondoc 1997, 271-275; Bondoc 2000, 177-182.

102 Benea 2005, 171-185.

${ }^{103}$ Vezi inscripția lui Sapor I, vezi la Dana, Nemeti 2000, 240-241.
} 
Trecerea prin canal era asigurată probabil prin tragerea de edec şi era supravegheată din punct de vedere militar.

La aceasta situație, determinată în principal de cauze naturale, se adaugă atacurile dacilor liberi asupra provinciilor de la Dunărea de Jos, care au avut loc într-un context general de atacuri asupra graniței Imperiului Roman (Germania, Africa, mişcări ale parților etc.), dar foarte probabil ele au fost determinate de anumite mişcări ale triburilor europene barbare, care au presat asupra populațiilor aflate în imediata apropiere a frontierelor romane. În acest context, se produc atacurile dacilor şi poate a unor aliați ai lor asupra Imperiului.

Chiar şi după pacificarea acestor triburi şi restabilirea ordinii în provinciile amintite concentrarea masivă de auxilii în provinciile dunărene nu va fi schimbată, ea fiind determinată de pregătirea campaniei parthice a lui Lucius Verus şi Marcus Aurelius. Este bine ştiut că la aceasta au participat din Moesia Inferior întreaga legiune V Macedonica, iar din Pannonia inferior legiunea II Adiutrix, ceea ce a determinat ca efective din legiunea IV Flavia să fie transferate temporar în castrul legiunii de la Aquincum. Aşa se face că toate auxiliile retrase din Dacia au fost fie incluse în vexilaţiile care au participat în campania din Orient, fie au fost distribuite pentru a suplini lipsa efectivelor din cele două provincii sud-dunărene. În acest context, Dacia a fost obligată pentru cele trei provincii ale ei să se descurce cu efectivele rămase. Poate acum se ridică (după atacurile din anii 155-157) şi valul median ce traversează sud-vestul Daciei, devenit limită a provinciei în acest sector ${ }^{104}$. Aceste evenimente militare sunt privite pe bună dreptate ca un preludiu al războaielor marcomanice.

Situația s-a perpetuat în deceniile care au urmat, iar menținerea trupelor pe ambele maluri ale Dunării şi după aceste evenimente este impusă de faptul că liniştea s-a restabilit greu, după peste două decenii de războaie cu marcomanii şi alte seminții, iar în secolul al III-lea s-a văzut că aceasta reprezenta singura soluție pentru controlul real al întregii zone.

Urmărirea cu atenție a atacurilor barbare la Dunărea de Jos conduce la concluzia că acestea s-au realizat în principal de-a lungul fluviului, prin fața Moesiei Inferior, lovind sectoarele slab apărate şi uneori provincia Dacia. Astfel, provincia nord-dunăreană a rămas uneori izolată, în ciuda puternicelor efective militare, situație care în final va conduce la abandonarea provinciei de către romani.

\section{LISTA ILUSTRAȚIILOR}

Fig. 1. Distribuția castrelor romane în regiunea Porților de Fier pe ambele maluri ale Dunării (apud Gudea 2001).

Fig. 2. Porturile militare din zona Porților de Fier (apud Petrović 1989-1990).

\section{BIBLIOGRAFIE}

\section{Izvoare literare}

Aelius Aristides, Discursuri, XXVI, 70

Cassius Dio, Istoria Romană

Historia Augusta

\footnotetext{
${ }^{104}$ Benea 2009a, 113-132.
} 


\section{BIBLIOGRAFIE MODERNĂ}

Bărbulescu 2006 - M. Bărbulescu, Un semicentenar la Daciei” în anii 157-158?, Daci şi Romani. 1900 de ani de la integrarea Daciei în Imperiul Roman, Timişoara 24-26 martie 2006 (ed. Doina Benea), BHAUT, 7, Timişoara, 126-135.

Benea 1983 - D. Benea, Din istoria militară a Moesiei Superior şi a Daciei. Legiunea a VII-a Claudia şi legiunea a IIII-a Flavia, Cluj Napoca.

Benea 1987 - D. Benea, Beiträge zur Geschichte der militärischen und mirtschaftlichen Beziehungen zwischen Dazien und Oberen Moesien (Das Gebiet Eisernene Tores im 2.-3.Jhr.), Actes du XII Congrès International d'Epigraphie Grecque et Latine, Athen 1982, Atena, 67-70.

Benea 2005 - D. Benea, Armata Daciei în timpul domniei lui Gordian al III-lea, Analele Banatului (In memoriam Florin Medeleț), 171-185.

Benea 2007 - D. Benea, Officinae plumbariae in der Provinz Dakien, Dacia Felix, 537-554.

Benea 2008 - D. Benea, Edificiul de cult roman de la Praetorium (Mehadia), Timişoara.

Benea 2009 - D. Benea, Despre războaiele cu dacii din timpul lui Antoninus Pius, Studia Archaeologica et Historica in honorem Magistri Dorin Alicu, Cluj-Napoca (eds. V. Rusu-Bolindeț, T. Sălăgean, R. Varga), Cluj-Napoca (sub tipar).

Benea 2009a - D. Benea, Betrachtungen über die Südwestgrenze der römischen Provinz Dakien. Der Stand der rumänischer Forschungen, Micellanea numismatica Antiquitatis. In honorem septuagenarii magistri Dan Teodor oblata (ediderunt Victor Spinei, Lucian Munteanu), Iaşi, 113-132.

Bondoc 1997 - D. Bondoc, Câteva piese sculpturale şi epigrafice aflate în Muzeul Olteniei Craiova, SCIVA 48, 3, 271-275.

Bondoc 2000 - D. Bondoc, A Detachment of Legio VII Claudia at Cioroiul Nou (Roumanie), Die Archäologie und Geschichte der Region des Eisernes Tores zwischen 106-275 n.Chr. Kolloquium in Drobeta-Turnu-Severin (1-4 Oktober 2000), 177-182.

Čermanović-Kuzmanović, Jovanović 2004 - Al. Čermanović-Kuzmanović, Al. Jovanović, Tekija, Belgrad.

Chițescu 1977 - M. Chițescu, Tezaure monetare ascunse pe vremea lui Antoninus Pius în Dacia, SCIV 22, 1, 401-410;

Daicoviciu, Piso 1975 - H. Daicoviciu, I. Piso, Sarmizegetusa şi războaiele marcomanice, ActaMN 13, 159-163

Dana, Nemeti 2000 - D. Dana, S. Nemeti, La Dacie dans les Gestae divi Saporis, ActaMN 38, 1, 239258.

Gerov 1977 - B. Gerov, Die Einfälle der Nordvölker in den Ostbalkanraum im Lichte der Münzschatzfunde, I, Das II. u. III. Jahrhundert (101-284), ANRW II, 6, 110-181.

Gaiu 2005. - C. Gaiu, Un depozit de antichităţi romane, Marmaţia 8, 215-225.

Gudea 1977 - N. Gudea, Gornea. Aşezări din epoca romană şi romană târzie, Reşita.

Gudea 1994 - N. Gudea, Dacia Porolissensis şi războaiele marcomanice, ActaMP 18, 67-93.

Gudea 2001 - N. Gudea, Die Nordgrenze der römischen Provinz Obermoesien. Materialien zu ihrer Geschichte (86-275 n.Chr.), JRGZM 48, 5-118.

Macrea 1969 - M. Macrea, Viaţa în Dacia Romană, Bucureşti.

Marinoiu 2002 - V. Marinoiu, Unitățile militare ce au staţionat în castrele de la Bumbeşti-Jiu, Argessis 11, 83-88.

Mihăilescu-Bîrliba 1980 - V. Mihăilescu-Bîrliba, La monnaie romaine chez les daces orientaux, Bucureşti. Mitrea 1957 - B. Mitrea, Contribuții numismatice la cunoaşterea luptei împotriva stăpânirii romane în Dacia, SCIV 5, 3-4, 467-486.

Moga, Benea 1975 - M. Moga, D. Benea, Tibiscum şi razboaiele marcomanice, Tibiscus 5, 124-136.

Onofrei 2007 - C. Onofrei, Maurii în Dacia, RB 21, 1, 283-291.

Petolescu 2000 - C. C. Petolescu, Dacia şi Imperiul Roman, Bucureşti.

Petolescu 2002 - C. C. Petolescu, Auxilia Daciae, Bucureşti. 
Petolescu 2003-2005 - C. C. Petolescu, Cronica epigrafică a României (XXI-XXIV, 2001-2004), SCIVA 54-55, 337-396.

Petrović 1989-1990 - P. Petrović, Classis Flavia Moesica na Dunavu u Gornjoj Meziji, Starinar, 4041, Beograd, 207-216.

Piso 1982 - I. Piso, Maximinus Thrax und die Provinz Dakien, ZPE 49, 247-257.

Piso 1993 - I. Piso, Fasti provinciae Daciae I. Die senatorischen Amsträger, Bonn.

Piso, Benea 1984 - I. Piso, D. Benea, Das Militärdiplom von Drobeta, ZPE 56, 263-295.

Protase 1967 - D. Protase, Legio IIII Flavia la nordul Dunării, ActaMN 4, 49-67.

Radnoti 1967 - A. Radnoti, Die Römische Reichsgrenze zwischen Belgrad und dem Eisernen Tor nach der Eroberung Dakiens, Arheološki Vestnik 26, 203-219.

Ritterling 1925 - Ritterling E., sv. Legio, RE, 1925, col. 1295

Starr 1961 - G. Starr, The Roman Imperial Navy 31 B.C.-324 A.D., Cambridge.

Stângă 1998 - I. Stângă, Viața economică la Drobeta în secolele II-VI p. Chr, Bucureşti.

Suciu 2000 - V. Suciu, Tezaure monetare din Dacia Romană şi postromană, Cluj-Napoca.

Thomasson 1977 - B. Thomasson, Laterculi Praesidum: Moesia, Dacia, Thracia, Göteborg.

Weiss 1999 - P. Weiss, Ein Diplom des Antoninus Pius für Moesia Inferior von Dez. 145/Dec. 146. Zum Truppenbestant der Provinz nach der Okkupation Dakiens, ZPE 124, 279-286. 


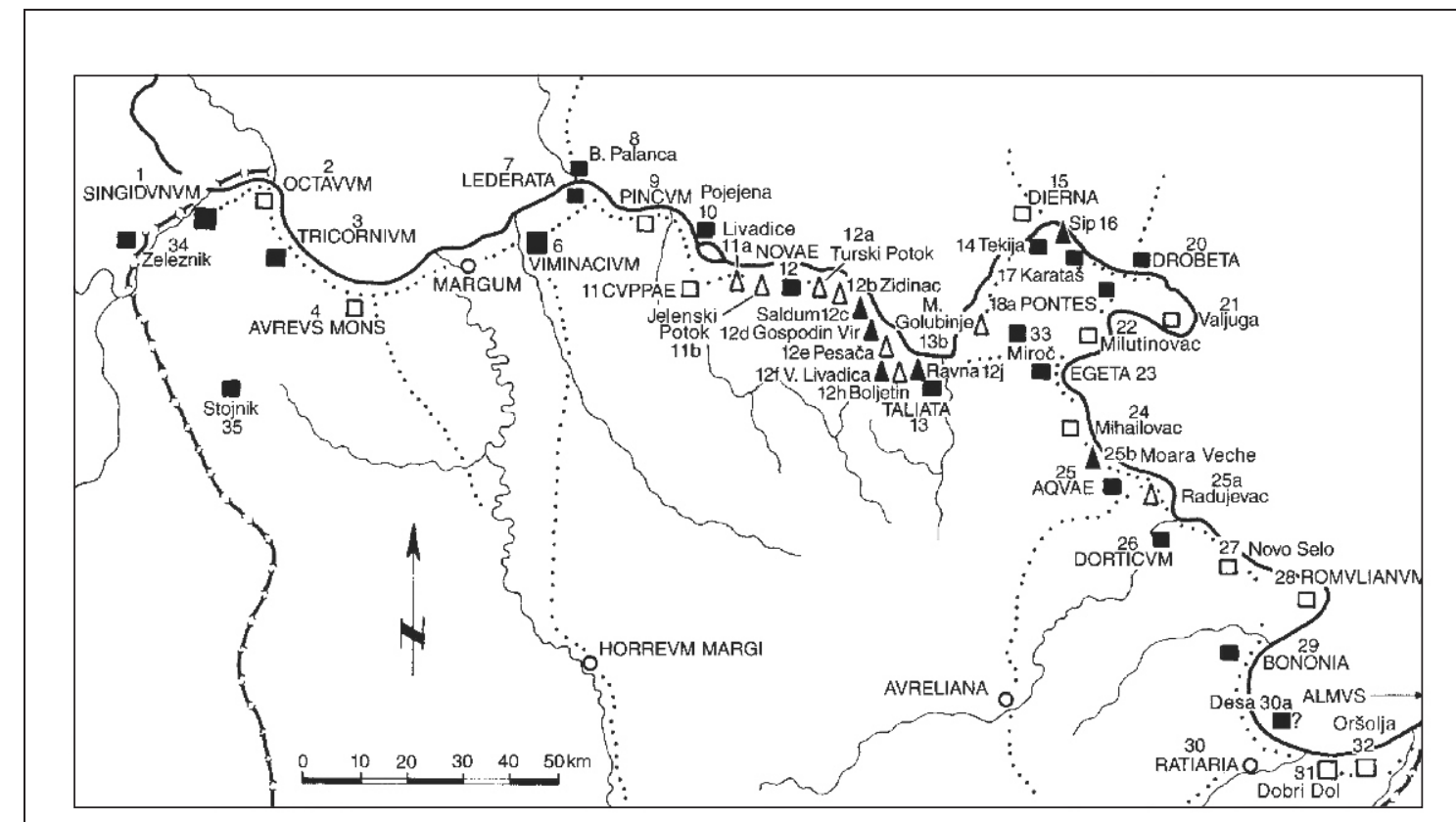

Fig. 1

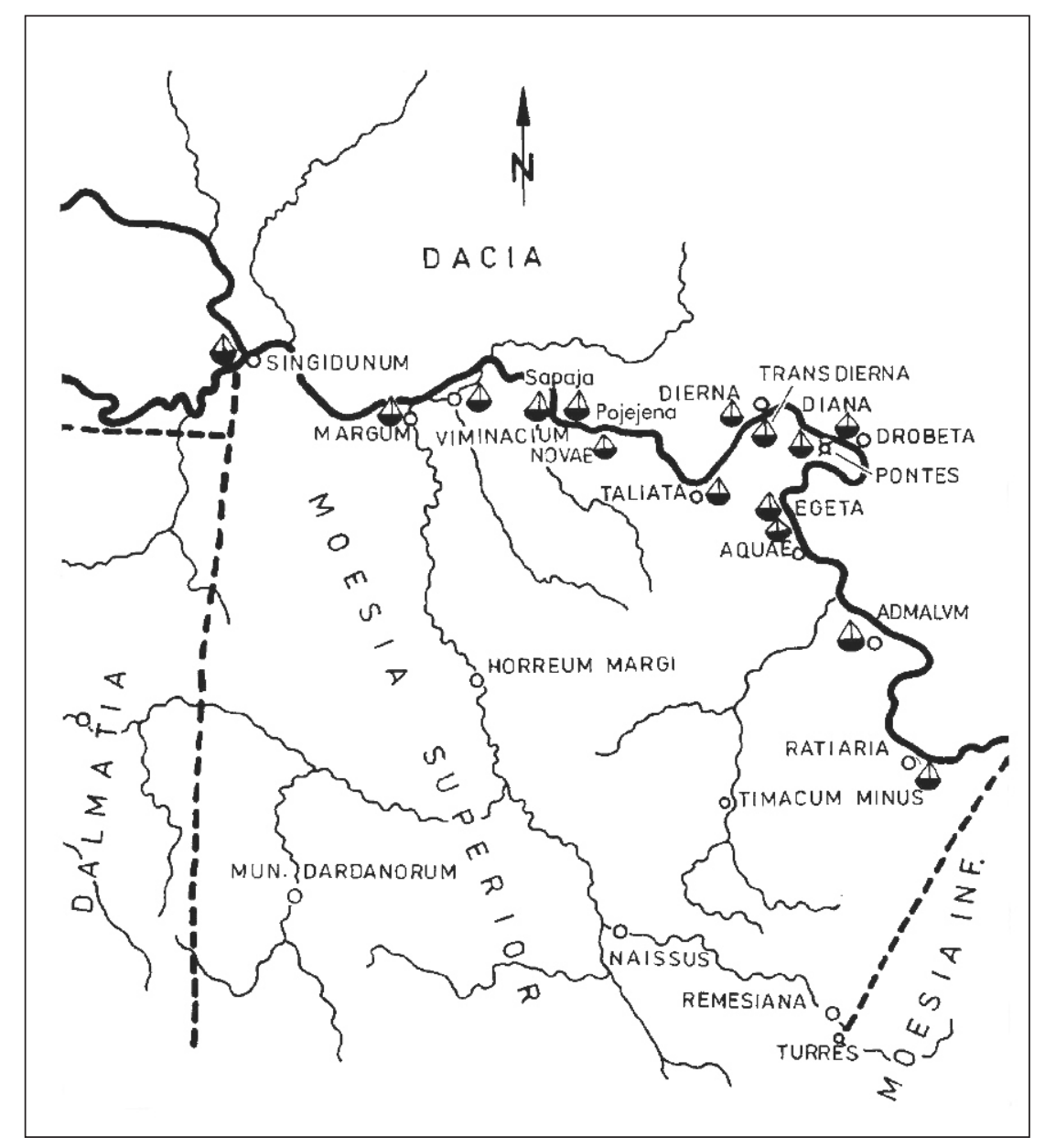

Fig. 2

PI. 1 